\title{
Revenue Process Internal Control For Manufacturers: An Evaluation Tool For Independent Auditors And Managers
}

Lou X. Orchard, Clayton State University, USA

Matthew L. Hoag, Gonzaga University, USA

\begin{abstract}
Effective management of the revenue process is critical to the success and long-run viability of any business. The revenue process also entails an elevated risk area for financial reporting fraud (AICPA 2002; Beasley et al., 2010). Accordingly, this important process demands heightened attention from independent auditors and company managers, and internal control activities must be considered as part of the ongoing evaluations of this important area. This paper presents a tool for evaluating internal control objectives and activities pertinent to the revenue process for companies operating in the manufacturing sector. This evaluation tool may be used by independent auditors as a general benchmark in performing a preliminary evaluation of a manufacturing client's internal control over the revenue process. Independent auditors who will find the tool most useful will primarily be those wishing to comply with U.S. Generally Accepted Auditing Standards (GAAS), including those performing integrated audit engagements in accordance with Public Company Accounting Oversight Board (PCAOB) Auditing Standard No. 5 and the new requirements set forth in the Committee of Sponsoring Organizations of the Treadway Commission's (COSO) Internal Control - Integrated Framework. In instances where important internal control activities have been omitted from the client's system, the auditor should consider whether the omission increases the risk of material misstatement. This tool may also be used by managers to evaluate the adequacy of their company's internal control activities within the revenue process.
\end{abstract}

Keywords: Internal Control; Revenue Process; Manufacturing; Independent Auditors

\section{INTRODUCTION}

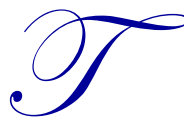

his paper presents a tool that may be used by independent auditors, as well as by managers in the manufacturing sector, to evaluate whether important revenue process internal control activities are in place. The independent auditors who will find the tool most useful are primarily those wishing to comply with U.S. Generally Accepted Auditing Standards, including those performing integrated audit engagements in accordance with PCAOB Auditing Standard No. 5, "An Audit of Internal Control over Financial Reporting that is Integrated with an Audit of Financial Statements" (AS 5). When performing an integrated audit, auditors must evaluate a client's internal control over financial reporting in accordance with guidance provided for in "Internal Control - Integrated Framework," issued by the Committee of Sponsoring Organizations of the Treadway Commission (COSO). COSO issued the current integrated internal control framework in 1992, but recently issued an updated framework, which supersedes the original framework beginning late in 2014, making this paper particularly timely.

This evaluation tool is potentially useful to auditors of both publicly-traded and privately-held manufacturers, as well as to managers of manufacturing companies who may have concerns about the quality of their company's internal control within the revenue process. Internal control is particularly important within the revenue process because revenue continues to be one of the primary areas affected by fraud and abuse (AICPA, 
2002; Beasley et al., 2010). ${ }^{1}$ The tool provided in this paper is also useful for manufacturing sector managers who face a sustained difficult operating environment in the wake of the recent financial crisis and corresponding global recession. ${ }^{2}$ In addition, these managers must continually adapt to an ever-changing business environment involving trends such as globalization, outsourcing, automation, and increased reliance on IT systems. According to COSO's integrated internal control framework, one of the overarching objectives of internal control is to provide reasonable assurance regarding the achievement of organizational objectives related to operational effectiveness and efficiency. Given the rapid shifts in the operating environment which accompany the trends referenced above, managers stand to benefit from periodically re-assessing organizational risks and evaluating whether the control activities in place reasonably ensure the entity's objectives are met.

\section{MANUFACTURING SECTOR BACKGROUND \& RECENT INDUSTRY TRENDS}

The manufacturing sector is very broad, encompassing firms that make everything from abrasives to wood floors, including both industrial and consumer products, as well as both finished products and materials used to manufacture finished products. Major product groups include food and beverages, chemicals, transportation equipment, and computers and electronics (First Research, 2013). According to the October 2013 Quarterly Manufacturing Sector update issued by First Research (a division of Hoover's), the global manufacturing sector produces more than $\$ 10$ trillion in annual revenue, with approximately half of that derived from U.S. manufacturers. Sector revenue is forecasted to grow at a moderate pace over the coming years. The leading drivers of that growth include rapid industrialization in the developing world, as well as the use of technology to improve products and supply chains (First Research, 2013).

Demand for manufactured goods is ultimately driven by consumer spending. The profitability of individual companies depends on their efficiency of production and distribution. Large manufacturers often have sizeable economies of scale in purchasing, production, and marketing. Small companies can effectively compete by producing specialized products for which large economies of scale do not exist. The manufacturing sector is fragmented, with the 50 largest companies accounting for less than half of manufacturing revenues (First Research, 2013).

A number of important trends have recently emerged within the manufacturing sector. As the sector, along with much of the world economy, continues a slow rebound from the depths of the 2007 financial crisis, managers must identify ways to streamline operations without sacrificing the integrity of the financial reporting and the proper application of key processes and procedures. Globalization entails new growth opportunities, but also entails new risks which must be properly mitigated by existing or new internal controls. Outsourcing and offshoring result from an increasingly globalized economy where transportation and communications costs continue to decline, thereby making it more cost effective to take advantage of lower wages outside of the U.S. ${ }^{3}$ Interestingly, the outsourcing and offshoring trends have reversed in a handful of areas within the manufacturing sector. A number of U.S. companies (including NCR, The Coleman Company, and others) have chosen to move at least part of their manufacturing operations from other countries to the U.S. (Delaware Valley Industrial Resource Center, 2013). Factors contributing to these decisions likely include the fact that middle-class wages are rising in high-growth countries like China, while the productivity levels of U.S. manufacturers remain relatively high (Boston Consulting Group, 2011; U.S. Bureau of Labor Statistics, 2013). The future significance to the overall economy of this "reshoring" activity of course remains to be seen.

\footnotetext{
${ }^{1}$ Beasley et al. (2010) investigate approximately 300 distinct cases of alleged fraud between 1998 and 2007 and find that $48 \%$ (132 of 273 ) of the alleged frauds involved a misstatement of revenue accounts. The next closest misstatement category was assets at $16 \%$ (44 of 273).

${ }^{2}$ Industrial production for 2011 was $90.3 \%$ of the level it was in 2007. It increased in 2012 to $93.9 \%$ of the 2007 level, and annualized industrial production in the first quarter of 2013 was $95.5 \%$ of the 2007 level (Federal Reserve, 2013). Put another way, industrial production increased only 1.6 percent between May 2012 and May 2013 (Moutray, 2013).

${ }^{3}$ The Boston Consulting Group estimated that average productivity-adjusted wage rates in China in 2010 were approximately $31 \%$ of average wage rates in the U.S., although this percentage was expected to increase to 44\% by 2015 (Boston Consulting Group, 2011, cited in Supply Chain Digest's On-Target e-Magazine, 2011). Comparing the most competitive regions of the U.S. (such as several Southern states) with the Yangtze River Delta (the region of China with the highest manufacturing output in the country), China's productivity-adjusted wage rates were estimated to be $48 \%$ of U.S. rates, which was expected to increase to $69 \%$ by 2015 .
} 
Another important trend involves the rapid automation of manufacturing processes and an increasing reliance on integrated IT systems throughout the manufacturing sector. For instance, new supply chain management systems allow manufacturers, suppliers, and customers to share information on orders, production schedules, and inventory levels in order to reduce costs and ensure timely order fulfillment. (First Research, 2013). An outcome of these trends is a growing dependency on IT systems and declining employee headcounts. While such trends are likely to provide cost savings and increased efficiencies in some areas, managers and auditors must consider the risks corresponding with an increased reliance on IT over manual processes.

Audit standards require that independent auditors obtain a thorough understanding of their clients including their respective business objectives, risks, and internal control activities; a task made more challenging given some of the significant trends referenced above. For instance, a manufacturing sector client may decide to offshore a key business function as a cost saving function, but may in turn find it difficult to implement a key internal control activity within their new foreign operations. Auditors may in turn conclude that the "offshored" business function represents a control weakness requiring additional attention and audit effort. The referenced manufacturing sector trends also present unique challenges to managers who must be nimble in responding to any new environmental risks that may arise. Managers must also examine their entity's internal control activities to evaluate whether the implemented policies and procedures effectively mitigate the risks that might prevent the company from achieving its strategic objectives.

\section{INTERNAL CONTROL WITHIN THE REVENUE PROCESS}

In May of 2013, COSO issued an updated internal control framework. This framework defines internal control as a process designed to provide reasonable assurance regarding the achievement of objectives relating to operational effectiveness and efficiency, reliability of financial reporting, and compliance with applicable laws and regulations (COSO, 2013). According to the framework, internal control consists of five integrated components: (1) Control Environment; (2) Risk Assessment; (3) Control Activities; (4) Information and Communication; and (5) Monitoring. The tool provided in this paper should be useful to independent auditors and manufacturing sector managers as a "memory jogging" resource when assessing key risks and identifying related control activities that have been implemented to mitigate the identified risks. Thus, the tool fits within the context of the "Risk Assessment" and "Control Activities" components of internal control as identified within the integrated framework. Table 1 lists seven key control principles identified by COSO which pertain to these two control components and relate closely to the evaluation tool.

Table 1: Key Principles for the Risk Assessment and Control Activities Components Internal Control - Integrated Framework (COSO, 2013)

\begin{tabular}{|l|l|}
\hline \multicolumn{1}{|c|}{ Risk Assessment } & \multicolumn{1}{|c|}{ Control Activities } \\
\hline $\begin{array}{l}\text { The organization specifies objectives with sufficient clarity to } \\
\text { enable the identification and assessment of risks relating to } \\
\text { objectives. }\end{array}$ & $\begin{array}{l}\text { The organization selects and develops control activities that } \\
\text { contribute to the mitigation of risks to the achievement of } \\
\text { objectives to acceptable levels. }\end{array}$ \\
\hline $\begin{array}{l}\text { The organization identifies risks to the achievement of its } \\
\text { objectives across the entity and analyzes risks as a basis for } \\
\text { determining how the risks should be managed. }\end{array}$ & $\begin{array}{l}\text { The organization selects and develops general control } \\
\text { activities over technology to support the achievement of } \\
\text { objectives. }\end{array}$ \\
\hline $\begin{array}{l}\text { The organization considers the potential for fraud in } \\
\text { assessing risks to the achievement of objectives. }\end{array}$ & $\begin{array}{l}\text { The organization deploys control activities through policies } \\
\text { that establish what is expected and procedures that put } \\
\text { policies into action. }\end{array}$ \\
\hline $\begin{array}{l}\text { The organization identifies and assesses changes that could } \\
\text { significantly impact the system of internal control. }\end{array}$ & \\
\hline
\end{tabular}

As highlighted in Table 1, managers must carefully identify objectives with sufficient clarity to enable the identification and assessment of risks to achieving these objectives. In addition, auditors must evaluate whether their client's internal control over financial reporting is effective in order to mitigate the risk of misstated and/or fraudulent financial statements (AS 5). To perform this evaluation, auditors must also consider the COSO framework and perform their own independent assessment of the risk of misstatement in the client's financial reporting. Weaknesses in their client's internal control would entail heightened control risk and increased risk of material misstatement and subsequently, auditors have to exert additional audit effort to achieve a reasonably low 
level of audit risk. Thus, both independent auditors and corporate managers must develop a robust understanding of strategic objectives, perform a comprehensive assessment of the risks to achieving these objectives, and evaluate the design and effectiveness of control activities currently in place to mitigate the assessed risks. The evaluation tool provided in the following section should assist auditors and managers alike in performing these important responsibilities within the context of a manufacturing business.

\section{REVENUE PROCESS INTERNAL CONTROL EVALUATION TOOL}

The evaluation tool is presented in two separate tables. Table 2 provides a summary of control objectives within the revenue process. Although COSO acknowledges three broad internal control objectives in the definition of internal control, the control objectives provided in Table 2 pertain to two of these objectives only (reliability of financial reporting and operational effectiveness and efficiency). Given that compliance control objectives vary widely from entity-to-entity, the tool does not include compliance control objectives. ${ }^{4}$ Each control objective in Table 2 is categorized within one of six revenue cycle sub-processes: (1) Sales Order Authorization; (2) Sales Order Entry and Processing; (3) Billing; (4) Collections; (5) Financial Reporting; and (6) General Control Activities. Each listed objective is also linked to one or more corresponding control activities using an alphanumeric referencing sequence. The numeric portion of each two- or three-character sequence refers to the control activities (which are listed numerically in Table 3). The letter portion for each sequence ("F" or "P") indicates whether the referenced control activity, if operating effectively, "fully" or "partially" meets the corresponding internal control objective.

Table 2: Control Objectives and Suggested Control Activities

\begin{tabular}{|c|c|}
\hline Control Objectives & Control Activities (by Ref.) \\
\hline \multicolumn{2}{|l|}{ (1) Sales Order Authorization Objectives } \\
\hline Orders are only processed within approved customer credit limits. & 25P, 28F, 29P, 39P, 66F \\
\hline Orders are approved by management as to prices and terms of sale. & $30 \mathrm{~F}, 40 \mathrm{~F}, 60 \mathrm{P}, 63 \mathrm{P}$ \\
\hline \multicolumn{2}{|l|}{ (2) Sales Order Entry and Processing Objectives } \\
\hline Orders and cancellations of orders are input accurately. & 31P, 32F, 33F, 34F, 41P, 57P \\
\hline $\begin{array}{l}\text { Order entry data is transferred completely and accurately to the shipping and } \\
\text { invoicing activities. }\end{array}$ & $35 \mathrm{~F}, 36 \mathrm{P}, 60 \mathrm{P}, 62 \mathrm{P}, 77 \mathrm{P}$ \\
\hline All orders received from customers are input and processed. & 32P, 34F, 36F, 38P, 72P, 77P \\
\hline Only valid orders are input and processed. & 32F, 34F, 36P, 42F, 57P, 60P \\
\hline \multicolumn{2}{|l|}{ (3) Billing Objectives } \\
\hline Invoices are generated using authorized terms and prices. & $4 \mathrm{P}, 9 \mathrm{~F}, 19 \mathrm{~F}, 30 \mathrm{~F}, 35 \mathrm{P}, 40 \mathrm{P}, 63 \mathrm{P}, 64 \mathrm{~F}$ \\
\hline Invoices are accurately calculated and recorded & $10 \mathrm{P}, 16 \mathrm{P}, 35 \mathrm{P}, 55 \mathrm{~F}, 56 \mathrm{~F}, 64 \mathrm{P}, 69 \mathrm{P}$ \\
\hline $\begin{array}{l}\text { Credit notes and adjustments to accounts receivable are accurately calculated } \\
\text { and recorded. }\end{array}$ & $10 \mathrm{P}, 14 \mathrm{~F}, 16 \mathrm{P}, 17 \mathrm{P}, 44 \mathrm{P}, 65 \mathrm{P}$ \\
\hline All goods shipped are invoiced. & $2 \mathrm{P}, 5 \mathrm{~F}, 9 \mathrm{~F}, 42 \mathrm{~F}, 45 \mathrm{~F}, 67 \mathrm{P}$ \\
\hline $\begin{array}{l}\text { Credit notes for all goods returned and adjustments to accounts receivable are } \\
\text { issued in accordance with organization policy. }\end{array}$ & $11 \mathrm{~F}, 44 \mathrm{~F}, 76 \mathrm{P}$ \\
\hline Invoices relate to valid shipments. & 1P, 9F, 24P, 43F, 73P, 74P \\
\hline All credit notes relate to a return of goods or other valid adjustments. & $11 \mathrm{~F}, 12 \mathrm{P}, 44 \mathrm{P}, 65 \mathrm{P}$ \\
\hline All invoices issued are recorded. & $8 \mathrm{P}, 37 \mathrm{~F}, 45 \mathrm{~F}, 68 \mathrm{P}, 77 \mathrm{P}$ \\
\hline All credit notes issued are recorded. & $12 \mathrm{~F}, 24 \mathrm{P}, 68 \mathrm{P}$ \\
\hline Invoices are recorded in the appropriate period. & $2 \mathrm{~F}, 8 \mathrm{P}$ \\
\hline Credit notes issued are recorded in the appropriate period. & $3 \mathrm{~F}, 12 \mathrm{~F}$ \\
\hline \multicolumn{2}{|l|}{ (4) Collections Objectives } \\
\hline Cash receipts are recorded in the period in which they are received. & $18 \mathrm{~F}, 46 \mathrm{~F}, 47 \mathrm{~F}, 48 \mathrm{~F}, 54 \mathrm{P}$ \\
\hline Cash receipts data is entered for processing accurately. & $24 \mathrm{P}, 46 \mathrm{~F}, 47 \mathrm{~F}, 48 \mathrm{P}, 49 \mathrm{P}, 50 \mathrm{P}, 54 \mathrm{P}, 58 \mathrm{P}, 59 \mathrm{P}$ \\
\hline All cash receipts data is entered for processing. & 24P, 46F, 47F, 48P, 50P, 51F, 54P, 58P \\
\hline Cash receipts data is valid and is entered for processing only once. & 46F, 48F, 51P, 54P, 63P \\
\hline Cash discounts are accurately calculated and recorded. & $52 \mathrm{~F}, 53 \mathrm{~F}, 75 \mathrm{P}$ \\
\hline Timely collection of accounts receivable is monitored. & $6 \mathrm{P}, 7 \mathrm{~F}, 58 \mathrm{~F}, 71 \mathrm{~F}$ \\
\hline
\end{tabular}

\footnotetext{
${ }^{4}$ Some of the listed control objectives may indeed work to mitigate risks of noncompliance with applicable laws and regulations, but the focus is on control objectives pertaining to the reliability of financial reporting and operational effectiveness and efficiency.
} 
Table 2 cont.

\begin{tabular}{|c|c|}
\hline \multicolumn{2}{|l|}{ (5) Financial Reporting Objectives } \\
\hline $\begin{array}{l}\text { Accounts receivable reflect the existing business circumstances and economic } \\
\text { conditions in accordance with the accounting policies being used. }\end{array}$ & $15 \mathrm{~F}$ \\
\hline $\begin{array}{l}\text { Sales and accounts receivable information is appropriately presented, and all } \\
\text { information that is necessary for fair presentation and compliance with } \\
\text { professional standards or legal requirements is disclosed. }\end{array}$ & $42 \mathrm{P}, 54 \mathrm{P}$ \\
\hline \multicolumn{2}{|l|}{ (6) General Control Activities Objectives } \\
\hline Only valid changes are made to the customer master file. & 13P, 20F, 26P, 57P, 70F \\
\hline All valid changes to the customer master file are input and processed. & $21 \mathrm{~F}, 26 \mathrm{P}, 27 \mathrm{~F}, 70 \mathrm{~F}$ \\
\hline Changes to the customer master file are accurate. & 20F, 22P, 26P, 57P, 61P, 70F \\
\hline Changes to the customer master file are processed in a timely manner. & $21 \mathrm{~F}, 26 \mathrm{P}, 27 \mathrm{~F}, 70 \mathrm{~F}$ \\
\hline Customer master file data remains pertinent. & 23P, 26P, 70P \\
\hline
\end{tabular}

Table 3: Suggested Control Activities

\begin{tabular}{|c|c|}
\hline Ref. & Control Activity \\
\hline 1 & $\begin{array}{l}\text { Signed delivery notes (proof of delivery) are received from customers for all shipments made. The sequence of signed } \\
\text { delivery notes received from customers is accounted for. }\end{array}$ \\
\hline 2 & $\begin{array}{l}\text { Goods shipped at, before, or after the end of an accounting period are scrutinized and/or reconciled to ensure complete } \\
\text { and consistent recording in the appropriate accounting period, including raising (creating) and recording of the related } \\
\text { invoices. }\end{array}$ \\
\hline 3 & $\begin{array}{l}\text { Goods returned by customers at, before, or after the end of an accounting period are scrutinized and/or reconciled to } \\
\text { ensure complete and consistent recording in the appropriate accounting period. }\end{array}$ \\
\hline 4 & $\begin{array}{l}\text { List prices of products assembled from components are automatically calculated based on the list prices of the } \\
\text { components of such products. }\end{array}$ \\
\hline 5 & $\begin{array}{l}\text { Goods on consignment are confirmed regularly and the statements are reconciled to inventory records and the general } \\
\text { ledger. }\end{array}$ \\
\hline 6 & Accounts receivable aging reports are prepared regularly and analyzed. \\
\hline 7 & Collection procedures established by management for overdue accounts are performed as intended. \\
\hline 8 & $\begin{array}{l}\text { Recorded sales, gross margins, and miscellaneous receipts are compared to the budget regularly; management reviews } \\
\text { and approves significant variances. }\end{array}$ \\
\hline 9 & $\begin{array}{l}\text { Data input to the invoicing subsystem is compared to priced order and shipment data per the separate, nonintegrated } \\
\text { order entry and/or shipping applications; differences require management approval before invoices can be processed. }\end{array}$ \\
\hline 10 & Invoice and credit note data is edited and validated; identified errors are corrected promptly. \\
\hline 11 & A policy has been established regarding criteria for issuing credit notes; compliance with this policy is monitored. \\
\hline 12 & Credit notes are sequentially prenumbered; the sequence of credit notes is accounted for. \\
\hline 13 & Significant changes to the customer master file are approved by management. \\
\hline 14 & Management approves credit notes, bad debt write-offs, and other adjustments to accounts receivable. \\
\hline 15 & Management reviews and approves the allowance for doubtful accounts. \\
\hline 16 & Invoice and credit note input data is balanced; out-of-balance batches are corrected promptly. \\
\hline 17 & $\begin{array}{l}\text { Management monitors the nature, volume, and amounts of recorded credit notes, write-offs, and other adjustments to } \\
\text { accounts receivable. }\end{array}$ \\
\hline 18 & $\begin{array}{l}\text { Cash receipts at, before, or after the end of an accounting period are scrutinized and/or reconciled to ensure complete } \\
\text { and consistent recording in the appropriate accounting period. }\end{array}$ \\
\hline 19 & $\begin{array}{l}\text { The system maintains both current and prior approved prices. Orders and invoices are priced using the price in effect } \\
\text { at the time of order placement or shipment, depending on the organization's policies and procedures. }\end{array}$ \\
\hline 20 & $\begin{array}{l}\text { Recording changes to customer master file data are compared to authorized source documents or confirmed with } \\
\text { customers to ensure that they were input accurately. }\end{array}$ \\
\hline 21 & $\begin{array}{l}\text { Requests to change customer master file data are logged; the log is reviewed to ensure that all requested changes are } \\
\text { processed in a timely manner. }\end{array}$ \\
\hline 22 & Customer master file input data is edited and validated; identified errors are corrected promptly. \\
\hline 23 & $\begin{array}{l}\text { Reports of customers who have not placed orders within a specified period of time are reviewed to ensure that } \\
\text { customer master file data remains pertinent. }\end{array}$ \\
\hline 24 & Statements of customer accounts receivable are mailed periodically to customers. \\
\hline 25 & Customers' financial position and creditworthiness are monitored. \\
\hline 26 & Customer master file data is periodically reviewed by management for accuracy and ongoing pertinence. \\
\hline 27 & $\begin{array}{l}\text { Requests to change customer master file data are submitted on prenumbered forms; the numerical sequence of such } \\
\text { forms is accounted for. }\end{array}$ \\
\hline
\end{tabular}


Table 3 cont.

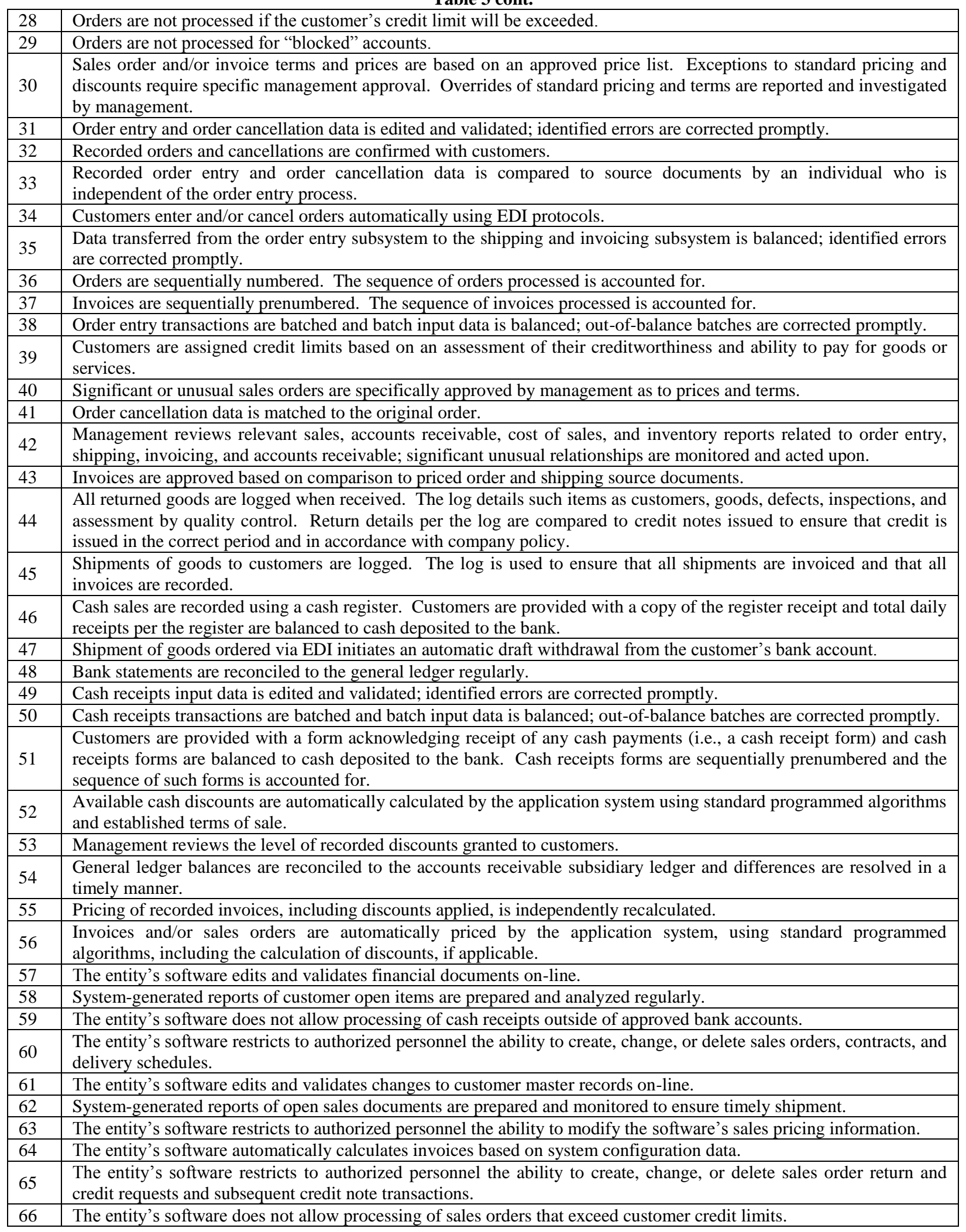


Table 3 cont.

\begin{tabular}{|l|l|}
\hline 67 & $\begin{array}{l}\text { System-generated reports of goods shipped but not invoiced and uninvoiced debit and credit note requests are prepared } \\
\text { and investigated promptly. }\end{array}$ \\
\hline 68 & System-generated reports of invoices issued but not posted in finance are prepared and investigated promptly. \\
\hline 69 & The entity's software posts invoices to general ledger accounts based on sales invoice configuration data. \\
\hline 70 & $\begin{array}{l}\text { System-generated reports of changes to customer master data are compared to authorized source documents and/or a } \\
\text { manual log of requested changes to ensure they were input accurately and in a timely manner. }\end{array}$ \\
\hline 71 & The entity's software accounts receivable aging reports are prepared regularly and analyzed. \\
\hline 72 & System-generated incompletion reports for sales documents are prepared regularly and analyzed. \\
\hline 73 & $\begin{array}{l}\text { The entity's software matches goods shipped to open line items on an open sales order and closes each item as the } \\
\text { goods are shipped, thereby preventing further shipments for those line items. }\end{array}$ \\
\hline 74 & $\begin{array}{l}\text { The entity's software restricts to authorized personnel the ability to create, change, or delete picking lists, delivery } \\
\text { notes, and goods issues. }\end{array}$ \\
\hline 75 & $\begin{array}{l}\text { The entity's software defines tolerance levels for allowable cash discounts and cash payment differences; amounts in } \\
\text { excess of such levels are not allowed to be entered into the system. }\end{array}$ \\
\hline 76 & The entity's software matches sales order return and credit request transactions to invoices. \\
\hline 77 & System-generated reports of gaps in document numbering are reviewed regularly. \\
\hline
\end{tabular}

\section{CONCLUSION}

This paper presents a tool for evaluating internal control within the revenue process of manufacturing sector companies. This evaluation tool will be useful to both independent auditors conducting a preliminary evaluation of internal control, as well as to industry managers who may have concerns about the adequacy of their company's internal control system. Internal control is critical to ensuring that manufacturing companies are able to meet their strategic objectives, which is especially important in light of the continuing struggles that these companies face in the wake of the 2007-2009 financial crisis and subsequent global recession. Further, industry trends related to globalization and a growing reliance on automation and information technology demand periodic re-evaluation of existing internal control activities. The evaluation tool is presented within the context of internal control evaluation guidance recently issued by COSO and slated to supersede in late 2014 the guidance currently in effect. Auditors and managers alike will be well served to familiarize themselves with this guidance as it pertains to their respective responsibilities.

Several limitations should be noted. This internal control evaluation tool is not intended to be a comprehensive guide to internal control over the revenue process. For instance, the tool emphasizes objectives pertaining to financial reporting reliability and operational effectiveness and efficiency, but it does not emphasize controls that might be deemed necessary by independent auditors conducting audits of compliance with government regulations which may apply to manufacturers doing business with the federal government. The tool also emphasizes control objectives and activities most directly related to the revenue process, and it does not expand upon control objectives and activities in related process areas such as the production and shipping functions. Finally, the tool is intended for auditors conducting their audits in accordance with U.S. GAAS or PCAOB Audit Standards, and will only be useful to auditors seeking to conduct audits in accordance with auditing standards of other jurisdictions to the extent that applicable U.S. auditing standards are consistent with auditing standards of these other jurisdictions.

\section{ACKNOWLEDGEMENT}

The authors wish to thank the management of a large anonymous Certified Public Accounting firm for allowing access to documents which were useful in the preparation of this paper.

\section{AUTHOR INFORMATION}

Lou X. Orchard, Ph.D., CPA, Associate Professor, College of Business, Clayton State University, 2000 Clayton State Boulevard, Morrow, Georgia, 30260-0285, USA, Phone (678) 466-4510. E-mail: LouOrchard@ @layton.edu 
Matthew L. Hoag, Ph.D., CPA, Assistant Professor, School of Business Administration, Gonzaga University, 502 East Boone Avenue, AD 9, Spokane, WA 99258-0009, USA, Phone (509) 313-7035. E-mail: hoag@jepson.gonzaga.edu (Corresponding Author)

\section{REFERENCES}

1. American Institute of Certified Public Accountants (AICPA) (2002). Consideration of fraud in a financial statement audit. Statement on auditing standards no. 99. New York, NY. Retrieved July 1, 2013 from http://www.aicpa.org/Research/Standards/AuditAttest/DownloadableDocuments/AU-00316.pdf

2. Boston Consulting Group (2011). Productivity-adjusted wage rates will near US rates by 2015, assuming current capital-labor tradeoffs and low-cost U.S. location (chart), shown in Supply Chain Digest's OnTarget e-magazine (2011). Retrieved June 30, 2013 from http://www.scdigest.com/ONTARGET/11-06-061.PHP?cid $=4609 \&$ ctype $=$ content

3. Beasley, M. S., Carcello, J. V., Hermanson, D. R., \& Neal, T. L. (2010) Fraudulent Financial Reporting 1998 - 2007: An analysis of U.S. public companies. Committee of Sponsoring Organizations (COSO), Jersey City, NJ.

4. Committee of Sponsoring Organizations of the Treadway Commission (2013). Internal ControlIntegrated Framework: Executive Summary. Committee of Sponsoring Organizations (COSO), Jersey City, NJ.

5. Delaware Valley Industrial Resource Center (2013). Manufacturing Success - Making it in the U.S.A. Retrieved July 9, 2013 from http://www.dvirc.org/manufacturing-success-making-it-in-the-u-s-a/

6. Federal Reserve (2013). Historical statistics for industrial production, capacity, and utilization: Manufacturing (seasonally adjusted). Retrieved July 8, 2013 from http://www.federalreserve.gov/releases/g17/current/table12.htm

7. First Research (2013, October 21). Manufacturing sector industry profile. First Research, a division of Hoover's, Inc., Austin, TX.

8. McNally, J. S. (2013). The 2013 COSO framework and SOX compliance: One approach to an effective transition. Committee of Sponsoring Organizations (COSO), Jersey City, NJ.

9. Moutray, C. (2013). Global Manufacturing Economic Update, June 14, 2013 (a publication of the National Association of Manufacturers). Retrieved July 9, 2013 from http://www.nam.org/Communications/Publications/Global-Manufacturing-EconomicUpdate/Archives/GMEU-061413.aspx

10. Public Company Accounting Oversight Board (PCAOB) (2007). Auditing Standard No. 5, An Audit of internal control over financial reporting that is integrated with an audit of financial statements. Washington, D.C. Retrieved July 1, 2013 from http://pcaobus.org/Rules/Rulemaking/Docket\%20021/200706-12_Release_No_2007-005A.pdf

11. U.S. Bureau of Labor Statistics (2013). Productivity change in the manufacturing sector, 1987-2012 (chart). Retrieved July 9, 2013 from http://www.bls.gov/lpc/prodybar.htm 